\title{
The Family Gap in Pay: \\ Evidence from Seven Industrialised Countries
}

\author{
Susan Harkness \\ Jane Waldfogel
}

\section{Contents}

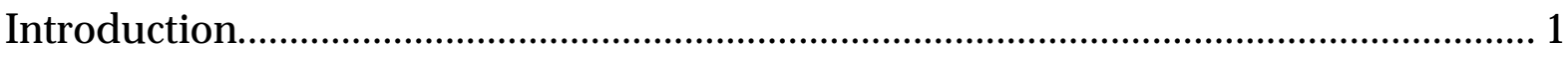

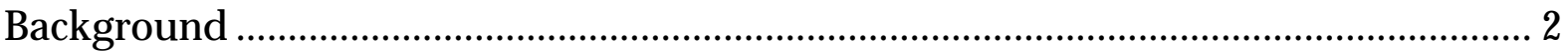

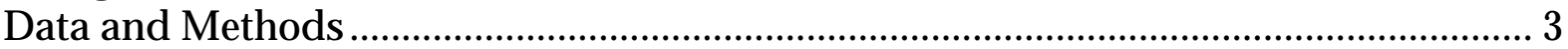

Raw Gender and Family Gaps in Employment and Wages ......................................... 4

The Effect of Children on Women's Employment....................................................... 7

The Effects of Children on Women's Wages .......................................................... 8

Differential Selection ............................................................................................. 11

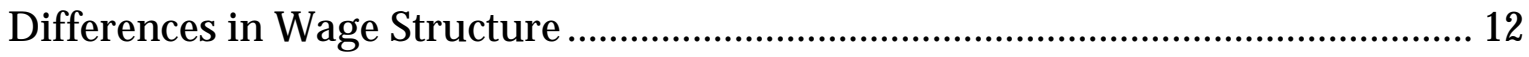

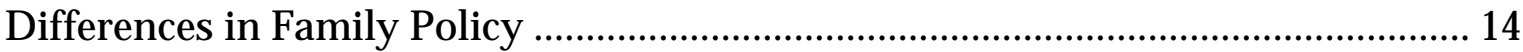

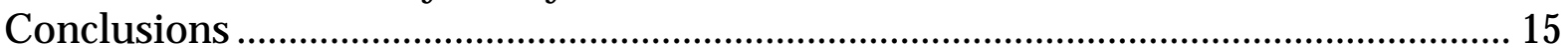

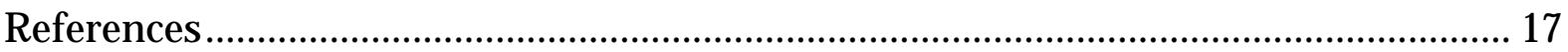

CASEpaper 29

November 1999
Centre for Analysis of Social Exclusion

London School of Economics

Houghton Street

London WC2A 2AE

CASE enquiries - tel: 02079556679 


\section{Centre for Analysis of Social Exclusion}

The ESRC Research Centre for Analysis of Social Exclusion (CASE) was established in October 1997 with funding from the Economic and Social Research Council. It is located within the Suntory and Toyota International Centres for Economics and Related Disciplines (STICERD) at the London School of Economics and Political Science, and benefits from support from STICERD. It is directed by Howard Glennerster, John Hills, Kathleen Kiernan, Julian Le Grand, Anne Power and Carol Propper.

Our Discussion Paper series is available free of charge. We also produce summaries of our research in CASEbriefs, and reports from various conferences and activities in CASEreports. To subscribe to the CASEpaper series, or for further information on the work of the Centre and our seminar series, please contact the Centre Administrator, Jane Dickson, on:

$\begin{array}{ll}\text { Telephone: } & \text { UK+20 } 79556679 \\ \text { Fax: } & \text { UK+20 7955 6951 } \\ \text { Email: } & \text { j.dickson@lse.ac.uk } \\ \text { Web site: } & \text { http://sticerd.lse.ac.uk/Case/ }\end{array}$

(C) Susan Harkness

Jane Waldfogel

All rights reserved. Short sections of text, not to exceed two paragraphs, may be quoted without explicit permission provided that full credit, including $\odot$ notice, is given to the source. 


\section{Editorial Note}

Susan Harkness is Lecturer in the Department of Economics at the University of Sussex and a research associate at the Centre for Analysis of Social Exclusion, London School of Economics. Jane Waldfogel isAssociate Professor in the Columbia University School of Social Work and a research associate at the Centre for Analysis of Exclusion, London School of Economics.

\section{Acknowledgements}

We are grateful to Tim Smeeding and Koen Vleminckx for their help with the Luxembourg Income Study data and to Anders Bjorklund and Johan Fritzell for their help with the Swedish data. Jane Waldfogel also gratefully acknowledges funding support from the William T. Grant Foundation and National Institute for Child Health and Development. 


\section{Abstract}

In this paper we use microdata on employment and earnings from a variety of industrialised countries to investigate the family gap in pay the differential in hourly wages between women with children and women without children. We present results from seven countries: Australia, Canada, the United Kingdom, the United States, Germany, Finland, and Sweden. We find that there is a good deal of variation across our sample countries in the effects of children on women's employment. We also find large differences in the effects of children on women's hourly wages even after controlling for differences between women with children and women without children in characteristics such as age and education.

Among the seven countries we study here, the United Kingdom displays the largest wage penalties to children. The family gap in pay is larger in the U.K. than in other countries because of the higher propensity of U.K. mothers to work in low-paid part-time jobs but also because even among full-timers, women with children in the U.K. are lower paid relative to other women than are mothers in other countries.

Why does the family gap in pay vary so much across countries? We find that the variation in the family gap in pay across countries is not primarily due to differential selection into employment or to differences in wage structure. We therefore suggest that future research should examine the impact of family policies such as maternity leave and child care on the family gap in pay. 


\section{Introduction}

Despite a good deal of progress in recent years, women still tend to have lower employment rates than men and to earn lower hourly wages if they do work. There is a large literature that examines the gender gap in pay within countries and a growing literature that examines the gender gap in pay across countries (see, for instance, Blau and Kahn, 1992, 1995, 1996, and 1999; Callan, Adams, Dex, Gustafsson, Schupp, and Smith, 1996). It is taken as given in these literatures that much of the differential between women and men is due to the fact that women bear children and have primary responsibility in most instances for caring or arranging care for them. Studies within countries provide evidence of a persistent family gap in pay between women with children and women without children (see, for instance, Joshi, Paci, and Waldfogel, 1999 on the U.K., and Waldfogel, 1997a on the U.S.). However, evidence comparing the family gap across countries has been lacking. Thus, we do not know whether countries have similar family gaps, or whether countries that have a larger family gap have a larger gender gap in pay. We also do not know much about the relationship between the employment effects of children and the wage effects of children. In countries where children have a large negative effect on women's employment, do they also have a large negative effect on women's wages, or is the opposite true? Put another way, do women in some countries accommodate their family responsibilities by reducing their employment while women in other countries instead remain in employment but at lower wages?

In this paper, we use microdata on employment and earnings from seven industrialised countries to address these questions. We find that there are large differences across countries in the family gap in pay. Among the seven countries we study here, the United Kingdom displays the largest wage penalties to children, because of the higher propensity of U.K. mothers to work in low-paid part-time jobs but also because even among full-timers, women with children in the U.K. are lower paid relative to other women than are mothers in other countries. We also find that there appears to be a relationship between the gender gap and family gap across countries. Countries where there is a large negative effect of children on women's pay tend to have a large gender gap in pay as well, and countries where mothers have lower employment rates have lower employment rates of women overall. We also find that in 
countries where children have a large negative effect on employment, they tend to have a large negative effect on pay as well.

\section{Background}

Welfare state analysts such as Gosta Esping-Anderson (1990) typically divide industrialised countries into three regime types: Anglo-Saxon or Anglo-American; continental European; and Scandinavian or Nordic. ${ }^{1}$ As we can see in Figure 1, the ratio of female to male hourly earnings has risen in countries from all three regime types in recent years. ${ }^{2}$ The figure also shows that the gender gap tends to be smaller in the Nordic countries and higher in the Anglo-American countries, with the continental European countries displaying a mixed pattern. Some analysts have linked these patterns to the pattern of family policy and equal opportunity policy on offer in these countries, arguing for instance that the Scandinavian countries' strong female-male earnings ratios reflect at least in part their strong family and equal opportunity policies while the weak performance of the Anglo-American countries reflects their more limited policies (Joshi, Paci, and Waldfogel, 1998; Waldfogel, 1998). ${ }^{3}$ Implicit in these analyses is the notion that lower wages for women with children in countries without well-developed family policies can go a long way towards explaining the higher gender gaps in those countries. However, direct evidence on this point has been lacking. Although there have been many analyses of the pay effects of children in recent years in the United Kingdom (see for instance Joshi 1991) and the United States (see for instance Korenman and Neumark, 1992; Neumark

1 See also Sainsbury (1995) whose typology takes gender more explicitly into account.

2 Figure 1 is based on data on hourly earnings of non-agricultural workers in selected industrialised countries. The U.K. data are from the Employment Department Historical Abstract, Yearbook of Labour Statistics, and subsequent Gazettes. The U.S. data are from the U.S. Bureau of Labor Statistics. Canada data are from the Survey of Consumer Finances, provided by Peter Kuhn. All other data are from the ILO Yearbook of Labour Statistics, various years, updated from material provided by Francine Blau. We are grateful to Wen-Jui Han for updating the data series and producing Figure 1 for us. For further information on the sources, see Blau and Kahn (1995), Waldfogel (1998), and Joshi, Paci, and Waldfogel (1998).

3 See also the work of Gornick, Meyers, and Ross (1998) who have examined the differences in institutional structure across a range of industrialised countries. 
and Korenman, 1994; Waldfogel 1997b), and at least one in Australia (Baxter, 1992), studies of the pay effects of children in Scandinavian and continental European countries have been much rarer. ${ }^{4}$ Moreover, even where studies exist, it can be difficult to compare results across studies given differences in samples, methodology, and so on. In this study, we overcome that difficulty by conducting our own estimates of the family gap in pay using comparable microdata from seven industrialised countries. In the sections that follow, we describe the data and methods and then present results. We conclude with suggestions for further research.

\section{Data and Methods}

Our data come primarily from the Luxembourg Income Study (LIS), a project in Walferdange, Luxembourg that brings together comparable microdata from a range of industrialised countries. We included in our sample every Western industrialised country in the LIS database for which gross hourly wages could be computed, in each case using the most recent year of data currently available. Because the Swedish dataset in LIS did not include earnings data, we instead used data from the most recent year (1991) of the Swedish Level of Living Survey (LNU), a nationally representative household dataset that is frequently used in studies of labour supply and earnings. 5 Our final sample includes at least one representative of each regime type. Our sample countries (and years) are: Australia (1994), Canada (1994), United Kingdom (1995), and United States (1994) from the Anglo-American group; Germany (1994) from continental Europe; and Finland (1991) and Sweden (1991) from the Nordic group.

For each of our sample countries, we use a sample of prime-age women and men, those between the ages of 24 and 44 . We exclude individuals younger than 24 in order to avoid estimating wage equations for young people who are still in full-time education. We

4 An important exception is a recent study by Albrecht, Edin, Sundstrom, and Vroman (1999) which found that in Sweden, children tended to have a positive or not significant effect on women's wages. See also Rosholm and Smith (1996) who find no significant effects of children on women's wages in Denmark.

5 The Level of Living Survey is used by permission of the Swedish Institute for Social Research in Stockholm, Sweden. For further information on this dataset, see Fritzell and Lundberg (1998). 
exclude individuals older than 44 because women in that age range who have no children are very likely to have had children in the past; thus, including women older than 44 would confound our comparison of women with children and women without children.

Our key outcome variables are: employment, defined as having a job during the survey week; full-time employment, defined as having a job during the survey week and working 30 or more hours per week; gross hourly wages, defined as gross annual earnings divided by annual hours worked (which is the product of weeks worked and hours worked per week); and the log of hourly wages. Individuals who describe themselves as self-employed are excluded from our sample, but all other workers are included. We particularly wanted to include part-time workers because of the importance of part-time work among women with children. However, as detailed below, we conduct some analyses separately for full-time workers due to concerns about measurement error and part- time wages. 6

The datasets held by LIS, and the LNU data for Sweden, contain detailed demographic and human capital information that we use to construct independent variables for our employment and wage models. A description of these variables is provided in the Appendix.

\section{Raw Gender and Family Gaps in Employment and Wages}

Table 1 provides an overview of the raw gender and family gaps in employment and full-time employment in our sample countries. Comparing all women in a country to all men in the same country, we find that the raw gender gap in employment ranges widely: it is largest in Australia, where women's mean employment rate is 24.8 percentage points lower than men's, and smallest in Sweden, where women's rate is 4.3 points higher than men's. However, even within countries, all women are not alike. Women without children are generally much more likely to work. In all but one of our sample countries, when we compare women with children to women without children, we find a substantial family gap in employment, ranging from a high of about 29 in Australia

6 For the most part, the data held by LIS have been cleaned and do not contain extreme values. However, this was not the case for the wage data for the United States. Therefore, for the U.S. sample, we had to exclude extreme wage values (wages less than $\$ 2.00 /$ hour or greater than $\$ 200 /$ hour); this affected only $1.3 \%$ of the observations in the U.S. sample. 
and the United Kingdom to a low of about 11 in Finland (the one exception is Sweden, where the employment rate of women with children is less than 1 percentage point lower than that of women without children). Turning to full-time employment in panel B of the Table, we find larger gender gaps but again a large range, with a high of 42.6 in Australia and a low of 0 in Finland, and even larger family gaps, ranging from a high of 50.9 in the United Kingdom to a low of 13.4 in Sweden.

Figure 2 shows how these mean employment rates vary by the age of the youngest child. Across all but one of our sample countries (Sweden again is the exception), employment rises as the age of the youngest child rises, but there are some differences in timing. In Australia and Germany, for instance, there is a sharp increase in employment when the youngest child turns one and another large increase as the youngest child moves from age five to age six or seven (which may reflect women returning to work when their children start school). In Canada and the U.S., employment is somewhat flatter in the early years and then increases from age five to six (when children start school), while in the U.K., employment is low (relative to Canada and the U.S.) throughout the pre-school years but then rises to Canadian and U.S. levels by age six. In Finland, employment rates rise as children age from one and two to four, but from a fairly high base, while in Sweden, employment rates hover at around 80 percent until children reach age seven at which point they rise to 85 or 90 percent. Interestingly, employment rates become very similar across our sample countries by the time children reach age 11 which probably reflects the fact that this is when children leave primary school and start middle or secondary school.

Table 1 and Figure 2 tell a fairly consistent story. Across our countries, women, and especially women with children, have lower levels of employment, with particularly large differences in mean levels of full-time employment. Figure 2 indicates that these differences are most pronounced for women with young children in most of our sample countries.

Table 2 shows the ratio of women's mean hourly wages to men's mean hourly wages for all women, and then women by family status, in our sample countries, and here the story is not so consistent across countries. The raw gender gap in pay varies a good deal by country, ranging from a high of 25.4 percent in the United Kingdom to a low of 11.8 percent in Australia. The raw family gap in pay varies as well: in five of our sample countries (Australia, Canada, Germany, Finland, and 
Sweden), women with children are paid about the same as or even more than women without children, while in the other two (the United Kingdom and the United States) there is a substantial family gap, 7.3 percent in the U.S. and 12.6 percent in the U.K. The pattern when only full-time workers are considered is much more consistent across countries, with the wages of women without children exceeding the wages of women with children in each of our sample countries and with the United Kingdom now looking much like the other countries. This difference in results is due to the fact that women who work part-time have much lower wages than full-time workers in the United Kingdom (see, for instance, Harkness, 1996) and to a lesser extent in the United States (see, for instance, Ferber and Waldfogel, 1998), whereas they are observed to have higher hourly wages than full-time workers in the raw data in several other of our sample countries. This latter finding raises the possibility that some of the part-time wages are measured with error; it is also possible that part-time workers in other countries do not face the steep wage penalties that part-timers are known to face in the United Kingdom and the United States.

The raw wage data in Table 2 indicate that there are substantial differences in the earnings of women with children and women without children in several of our sample countries, and in all our countries when only full-timers are considered. The raw wage data also suggest that there is some relationship between a country's gender gap in pay and its family gap in pay. When we plot a country's gender gap in pay and its family gap in pay (see Figure 3), we find that countries with higher family gaps in pay do tend to have higher gender gaps in pay. Interestingly, we also find that countries with higher gender employment gaps tend to have higher family employment gaps (see Figure 4).

The raw data can also tell us something about the relationship of the employment and wage effects of children. Is it the case that countries where the employment rate of mothers is much lower than that of other women are also countries where the wages of mothers are much lower than those of non-mothers? Or, is there a trade-off, such that women with children either reduce their employment, or work at lower wages? Figure 5, which plots a country's employment gap between mothers and non-mothers against its wage gap between mothers and non-mothers, suggests that there is no simple relationship between a country's family gap in pay and its family gap in employment, but for the most part the relationship appears to be positive. 
The raw data, however, can not tell us to what extent the employment and wage gaps between mothers and other women simply reflect differences in human capital or demographic characteristics between the two groups. Therefore, in the next sections, we estimate the effects of children on women's employment and wages, controlling for other characteristics.

\section{The Effect of Children on Women's Employment}

We model a woman's employment decision as a function of her responsibility for children which we measure with a set of dummy variables for the age of her youngest child, using the three categories youngest child under age one (infant), youngest child age one to five (pre-schooler), or youngest child age six to seventeen (school-age child). Because the presence of a husband may affect a woman's employment decision, we also control for marital status by including a dummy variable for being married.7 Our model also includes controls for the following human capital and demographic variables: age and its square, a set of dummy variables for level of education, a set of dummy variables for ethnicity, the amount of other family members' earnings, the amount of other family income, and a set of dummy variables for region and whether the woman resides in an urban area. We estimate similar models for full-time employment (defined as working 30 or more hours per week).

Results for our seven sample countries from linear probability models of employment and full-time employment estimated using ordinary least squares (OLS) are shown in Table $3.8^{8}$ In all four AngloAmerican countries and in Germany, the age of the youngest child exerts a large influence on women's employment. As suggested by the raw data in Figure 2, employment of women in these countries rises steadily as the youngest child ages. Marriage, in contrast, seems to be less important, exerting a small positive effect in Canada and the U.K., and no significant effect in the other Anglo-American countries and

$7 \quad$ Means for the family status variables are shown in the Appendix. Note that there may be some ambiguity in the coding for Germany, where we find very few women with a child age 0 in the data. As noted in the appendix, the category of married includes those living as married in all of our sample countries except the U.S. and Germany.

8 Marginal effects from probit models, not shown here, display a similar pattern. 
Germany. The results for the Nordic countries are different, as we might have expected given the pattern of the raw data in Figure 2. In both Finland and Sweden, women with infants and pre-school age children, but not school age children, are significantly less likely to be employed, but the effects are small (ranging from 9 to 12 percent) compared to the effects for the Anglo-American countries and Germany. ${ }^{9}$ Marriage lowers women's employment in Sweden, but not in Finland.

The results for full-time employment are similar. We find very large negative effects of children, generally declining by the age of the child, in the Anglo-American countries and Germany. The effects are particularly large in the U.K., as would be expected given the greater propensity of women with children to work part-time in that country as compared to our other sample countries. In contrast, we find much smaller effects of children in Finland and Sweden. Being married again has a negative effect in Sweden; we also see a negative effect of being married on full-time employment in Germany and the U.S., and a small positive effect in Canada.

Although the pattern of results is similar for the four AngloAmerican countries and Germany, it is worth noting that the magnitude of the effects varies a good deal across these countries. Children reduce women's employment much more in Australia, Germany, and the United Kingdom than they do in Canada and the United States, with particularly large effects for full-time employment in the U.K.. And, in turn, children have a much larger effect on women's employment in these countries than they do in our two Nordic countries. This variation across countries raises the question of the extent to which institutional or policy differences might moderate the effects of children on women's employment and thus account for some of the differences across countries. We discuss this question further below.

\section{The Effects of Children on Women's Wages}

We estimate human capital earnings functions with the natural logarithm of hourly wages as our dependent variable and a set of family

9 The small effect of children under the age of one on women's employment in Finland and Sweden probably reflects the fact that these countries have very generous parental leave provisions which many women take advantage of. Since women on maternity leave are counted as employed, the high share of women taking maternity leave would boost the share employed among women with children under the age of one. 
status and other variables (detailed below) as our independent variables. To control for a woman's responsibility for children, we include controls for the number of children, with dummy variables for one child, two children, or three or more children.

There are many reasons why children might affect women's wages (see Mincer and Polachek, 1974; Becker, 1985; Hakim, 1996). Children may affect women's wages directly, by for instance lowering a woman's effort on the job, or indirectly, by for instance lowering the amount of work experience and job tenure a woman accumulates over time. The fact that women with children are lower paid may reflect choices employees have made (for instance, to trade more flexible hours for lower wages), or it may reflect employer preferences or discrimination. Since we can not control for effort, experience, tenure, employee choices, or employer preferences or discrimination in our datasets, we do not place too strong an interpretation on the wage effects of children. We are simply interested in finding out whether such effects exist in our sample countries and how much they vary across countries once we control for other characteristics.

Our wage model includes, in addition to the child variables, controls for: marriage; age and its square; a set of dummy variables for level of education; a set of dummy variables for ethnicity; and a set of dummy variables for region and whether the woman lives in an urban area. Because as noted earlier, we are concerned about the possibility of measurement error in the part-time wages, we estimated this model once for all workers and then for full-time workers only. ${ }^{10}$

The results of the wage models are shown in Table 4 . In our results for all workers, shown in panel 1, we find sizeable negative effects of children on women's wages in all four Anglo-American countries. Because our dependent variable is the log of hourly wages, the coefficients can be interpreted as percentage effects. Thus, looking at the Anglo-American countries, we find a pay penalty for one child that ranges from a low of about 4 percent in Canada and the U.S. to a high of 8 percent in the U.K., a pay penalty for two children that ranges from 5 percent in Canada to 24 percent in the U.K, and a pay penalty for three

10 We also estimated models in which we added a control for whether the woman works part-time (less than thirty hours per week) since working parttime may account for some of the lower wages of women with children. The results of these models (not shown) suggest that although working part-time does have a significant negative effect on women's hourly wages in two of our countries (the U.S. and U.K), significant negative effects of children in those countries remain even after controlling for part-time working status. 
or more children that ranges from 10 percent in Australia to 31 percent in the U.K.. It is worth noting that in each instance, the pay penalty to children is higher in the U.K. than in the other Anglo-American countries. The results for Germany are less conclusive, with an 11 percent penalty for two children but no significant penalties for one child or for three or more children. In Finland, in contrast, we find only a small penalty to one child (4 percent) or three or more children (6 percent), and no significant penalty for two children, while in Sweden, we find no significant child penalties at all.

The second panel in the Table shows the results of the same model but this time estimated only for full-time workers. When we restrict our sample to full-time workers, we find generally larger negative effects of children in five of our countries (Australia, Canada, Germany, Finland, and Sweden) and smaller effects in the other two countries (the U.K. and U.S.). Nevertheless, the overall pattern of results is similar to that found for all workers, with the largest pay effect of two or more children are found in the U.K.. Thus, the lower pay of mothers in the U.K., relative to other women in that country, is not due solely to the fact that they are more likely to work in low-paid part-time jobs, since a substantial pay penalty to children remains even among full-timers. At the other end of the spectrum, the penalties become somewhat larger in Finland and Sweden when we restrict the sample to full-time workers, but they are still low relative to other countries. The results for the U.S. are also of interest. Here, the child penalties become somewhat smaller when we restrict the sample to full-time workers; indeed, the penalties in the U.S. are comparable to those in the Nordic countries.

Taken together, these wage models provide fairly robust evidence of negative pay effects of children across our sample countries. Even more interestingly, they also provide evidence that these effects vary a great deal by country. As noted above, we can not definitively explain these negative pay effects of children - they may reflect individual factors such as effort, experience, or tenure, or employee choices, or employer factors such as preferences or discrimination that we do not observe in our datasets 11 - but it is worth speculating as to why they vary so much across countries. We consider three alternative explanations below.

11 Some portion of these pay penalties may be due to differences in the occupations of women with children and women without children. We plan to explore this in future research. 


\section{Differential Selection}

One possibility is that the difference in the negative pay effects of children across countries reflects the differential selection of women into employment across our sample countries. If women with children and low earnings potential are more likely to work in the Anglo-American countries, for instance, then the pool of working mothers might include more women with lower wages and thus we would estimate a larger negative effect of children on women's pay. However, as we saw in Figure 5 earlier, the employment and wage effects of children tend to be correlated. In countries such as the Anglo-American group where children have a large negative effect on wages, they also tend to have a large negative effect on employment. This evidence does not support the hypothesis that differential selection into employment plays an important role in explaining the differences in the pay effects of children across countries.

To test this hypothesis more formally, we estimated Heckman (1979) sample selection correction models, using the age structure of the children in the household, the amount of other family members' earnings, and the amount of other family income as our identifying variables. Specifically, we included in our wage models the same variables as before (age, age squared, controls for level of education, race/ethnicity, married, dummy variables for one child, two children, or three or more, region, and urban residence), while including in our employment probit models age, age squared, controls for level of education, race/ethnicity, married, number of children under age 1 , number age 1 to 4 , and number age 5 to 17, other family members' earnings, other family income, region, and urban residence. ${ }^{12}$

The results, shown in Table 5, suggest that the estimated effects of children on women's pay are not affected a great deal by sample selection bias. The sample selection correction term, lambda, is not statistically significant in any of our countries except the U.S., where the sample selection term, lambda, is strongly positive (suggesting that women who work have higher wages than non-working women with similar characteristics would have if they worked). And, the relative ranking of the countries in terms of the magnitude of their family penalties is much the same as it was in the uncorrected wage models, shown in Panel 1 of Table 4: the U.K. has the largest pay penalties to children, followed by the other three Anglo-American countries, then

12 We also estimated similar models for selection into full-time employment. The results of these models are available upon request. 
Germany, and then the two Nordic countries. This evidence does not favour selection as a primary reason for the differences in the family gap in wages across countries.

\section{Differences in Wage Structure}

Another possibility is that the differences in the wage effects of children across countries reflect differences in wage structure. A series of studies by Blau and Kahn $(1992,1995,1996$, and 1998) have found that to a large extent, the difference in the gender earnings gap across countries can be explained by the difference in the extent of earnings inequality across countries. Blau (1992) illustrates this by first ranking countries by their gender earnings ratios and then ranking countries by their mean female percentile in the male wage distribution. This exercise shows that a country such as Sweden has a high gender earnings ratio (77.2 percent in her data) in spite of having a relatively low female percentile (27.6) in the male wage distribution, while a country such as the U.S. has a low gender earnings ratio (66.9 percent) in spite of having a higher female percentile (33.2) in the male wage distribution. The reason for this discrepancy between the two measures is that the penalty for one's position in the wage distribution varies widely across countries, depending on the dispersion of earnings in a country; in the above example, the penalty for a low percentile position is greater in the U.S. than in Sweden, because the U.S. has a more unequal wage structure. Thus, if one wants to understand the difference in the gender pay gap between two countries such as the U.S. and Sweden, taking wage structure into account is important. 13

This explanation, however, may not fit as well when it comes to explaining differences in the family gap in pay across countries. Consider Table 2, panel A, which shows that among all workers the wages of women with and without children are nearly identical in Finland and Sweden. In this case, wage structure would not explain the smaller family gap in these two Nordic countries; the main reason for the smaller family gap is that there is little or no difference in pay between women with and without children, not that the difference is penalised less than it is in other countries.

To illustrate this more clearly, we calculated the position of each women in each country in the male earnings distribution in their

13 In a similar vein, Edin and Richardson (1999) find that changes in solidarity wage policy have been an important factor in narrowing the gender earnings gap within a country (Sweden) over time. 
country, and then calculated the average percentile ranking of women in each country. The results are shown in Table 6. Looking first at the results for all workers, we can see that in four countries there is at most a 1 or 2 point family gap as measured by the difference between the mean percentile rankings of women with children and women without children: in Australia, both women with children and women without children have wages that are on average at about the 40th percentile of the male wage distribution; in Canada, women with children are at the 38th percentile while women with children are a few points behind at the 36th percentile; in Finland, women with children are at the 36th percentile while women with children are 1 point behind at the 35th percentile; and in Sweden, women with children are at the 32nd percentile while women with children are 1 point behind at the 31st percentile. The results for the other three countries are quite different: in the United States and Germany, there is about a 6 point family gap, with women without children at the 42 nd (U.S.) or 43rd (Germany) percentile and women with children at the 37th percentile; and in the U.K., the family gap is over 11 points, with women without children at the 40th percentile as compared to women with children at the 29th percentile. ${ }^{14}$ Overall, these results are quite consistent with the pattern of results we obtain when we use the gender earnings ratio as our measure, as we can see in Figure 6. On both measures, we find the largest family gaps in pay in the U.S., Germany, and the U.K..

Following Blau (1992), it is informative to compare the rankings of countries using the percentile position of women with their rankings using the gender pay ratio, as this will tell us how important a role wage structure plays in the differences across countries. Given our interest in the position of women with children as compared to women without children, we compare these groups separately, as shown in Figure 7.

Looking first at the non-mothers, we find that using the mean percentile ranking as opposed to the mean gender pay ratio changes the ranking of our countries a good deal, with only two of our seven countries (Germany and Finland) not changing position. However, there is relatively little spread between countries to start with, since across all

14 When we restrict the analysis to full-time workers only, the percentile ranking of U.K. women with children improves dramatically, which makes sense given the links in that country between motherhood, part-time work, and low pay, whereas we find the opposite result for Sweden, where as we saw earlier the wages of mothers who work full-time tend to be somewhat lower than those of mothers who work part-time. 
seven, the pay ratio of non-mothers relative to men is in the range of 82 to 88 percent.

When we turn to mothers, we find a much larger spread, with the pay ratio of mothers relative to non-mothers ranging from a low of 70 percent in the U.K to a high of 91 percent in Australia. In contrast to our results for non-mothers (and to Blau's (1992) results for women overall), measuring mothers' pay by their mean percentile ranking in the male distribution does not for the most part alter the ranking of the countries. Only two countries change position: Sweden moves down from 3rd to 6th place while the U.S. moves up.

Thus, wage structure seems to be important in understanding why mothers are lower paid relative to men in the U.S. than they are in Sweden. But, at the same time, wage structure does not help very much in explaining why mothers are lower paid relative to non-mothers. If a country such as the U.K. adopted Sweden's pay structure, this would reduce the penalty that mothers face in the labour market for being at a lower percentile in the male wage distribution but it would not change the fact that they are at a lower position. More generally, changing the pay structure would not eliminate the family gap in pay in the U.K. or the U.S. or Germany, since mothers in those countries are at a much lower percentile ranking than non-mothers to start with.

\section{Differences in Family Policy}

A third possible explanation for the differences in the family gap in pay across countries is the variation in family policy. We are not able to examine this explanation here, because we have data from only one point in time. 15 Thus, whether adopting changes in family policy such as maternity leave or child care would improve the pay position of mothers is an open question. It is possible that the parity achieved by Nordic mothers relative to non-mothers comes about as a result of their extensive family policies, which support the labour force attachment of women with children and thus are likely to raise women's levels of work experience and job tenure (Waldfogel, 1998; Joshi, Paci, and Waldfogel, 1998). But this parity may come at the price of lower wages for women overall, if employers shift the costs associated with such policies to those perceived to be most likely to benefit from them, namely, women. The low position of all Swedish women in the male wage distribution may

15 We hope to be able to address this issue in future work, by using multiple wave of data from LIS in conjunction with data on policies and institutions in the various countries. 
reflect the price women pay for Sweden's extensive family policy supports, or it may reflect other factors entirely. More research on this question, and on the impact of family policies more generally on the employment and pay of mothers, and non-mothers, is warranted.

\section{Conclusions}

This paper is the first to tackle the question of whether the family gap in pay that has been documented for some Anglo-American countries is unique to those countries or whether a comparable gap is found in other Western industrialised countries. The results for the seven countries examined here indicate that, controlling for differences in earningsrelated characteristics, the effect of children on women's pay is largest in the United Kingdom (in large part, because of the tendency of mothers in the U.K. to work in poorly paid part-time jobs), followed by the other Anglo-American countries and Germany, and smallest in the Nordic countries.

We also sought to learn whether there is a link between the family gap and gender gap in pay across countries, such that countries with higher family gaps tend to have larger gender gaps as well. This was in fact the case in our data, as we saw in Figure 3, with the U.K. displaying both the largest gender gap and the largest family gap in pay. We also examined the relationship between the employment gap between mothers and other women, and the wage gap between mothers and other women, and found that they were positively correlated. Thus, we found no evidence that women with children make a choice between lower employment or lower wages; the two seem to go together. This suggests that the high pay penalty to children in the U.K., for instance, is not simply due to the fact that women with children are more likely to work in that country. We tested this more formally by estimating models corrected for sample selection bias, but again we found little evidence to support the hypothesis that differential selection into employment accounts for the differences in the family gap across countries. Nor did we find much evidence that differences in wage structure explain the cross-country differences in the family gap.

Why does the family gap in pay vary so much across countries? What role do family policies such as maternity leave and child care play in closing the pay gap between mothers and other women? And what impact do such policies have on the pay of women overall? This study, 
using data from one point in time, could not answer these questions, but our results suggest that they are worth investigating in future. 


\section{References}

Albrecht, James, Per-Anders Edin, Marianne Sundstrom, and Susan Vroman (1999), "Career Interruptions and Subsequent Earnings: A Re-examination Using Swedish Data", Journal of Human Resources, 34(2): 294-311.

Baxter, Denise (1992), "Domestic Labour and Income Inequality", Work, Employment, and Society, 6(2): 229-249.

Becker, Gary (1985), "Human Capital, Effort, and the Sexual Division of Labour", Journal of Labour Economics, 3: 33-38.

Blau, Francine (1992), "Gender and Economic Outcomes: The Role of Wage Structure", Keynote Speech, Fourth European Association of Labour Economists Annual Conference, Warwick, England.

Blau, Francine and Lawrence Kahn (1992), "The Gender Earnings Gap: Learning from International Comparisons", American Economic Review, 82 (May): 533-538.

Blau, Francine and Lawrence Kahn (1995), “The Gender Earnings Gap: Some International Evidence", pp. 105-143 in Richard Freeman and Lawrence Katz (eds.), Changes and Differences in Wage Structures. Chicago: University of Chicago Press.

Blau, Francine and Lawrence Kahn (1996), "Wage Structure and Gender Earnings Differentials: An International Comparison." Economica, 63 (Supplement): S29-S62.

Blau, Francine and Lawrence Kahn (1999), "The Effect of Wage Inequality and Female Labour Supply on the Gender Pay Gap: A Cross-Country Analysis, 1985 to 1994", Working Paper, Cornell University, Ithaca.

Callan, Tricia, S. Adams, Shirley Dex, Siv Gustafsson, J. Schupp, and Nina Smith (1996), "Gender Wage Differentials: New CrossCountry Evidence", Working Paper No. 134, Luxembourg Income Study, Walferdange, Luxembourg.

Edin, Per-Anders and Katarina Richardson (1999), "Swimming with the Tide: Solidarity Wage Policy and the Gender Earnings Gap." Working Paper 1999-02-18, Uppsala University.

Esping-Anderson, Gosta (1990), Three Worlds of Welfare Capitalism. Princeton: Princeton University Press. 
Ferber, Marianne and Jane Waldfogel (1998), "The Long-Term Consequences of Non-Standard Work." Monthly Labour Review, 121(5): 3-12.

Fritzell, Johan and O. Lundberg (eds.) (1994), Vardagens villkor. Levnadsförhållanden I Sverige under tre decennier (Every day life. Living conditions in Sweden during three decades). Stockholm: Brombergs.

Gornick, Janet, Marcia Meyers, and Katherin Ross (1998), "Public Policies and the Employment of Mothers", Social Science Quarterly, 79(1): 35-54.

Hakim, Catherine (1996), Key Issues in Women's Work: Female Heterogeneity and the Polarisation of Women's Employment. London: Athlone.

Harkness, Susan (1996), "The Gender Earnings Gap: Evidence from the U.K.", Fiscal Studies, 17(2): 1-36.

Heckman, James (1979), "Sample Selection Bias as a Specification Error." Econometrica, 47: 153-161.

Joshi, Heather (1991), "Sex and Motherhood as Handicaps in the Labour Market", in Dulcie Groves and Mavis Maclean (eds.), Women's Issues in Social Policy. London: Routledge.

Joshi, Heather, Pierella Paci, and Jane Waldfogel (1998), "What Do We Know about Unequal Pay?", in Heather Joshi and Pierella Paci, with Gerald Makepeace and Jane Waldfogel, Unequal Pay. Cambridge: MIT Press.

Joshi, Heather, Pierella Paci, and Jane Waldfogel (1999), "The Wages of Motherhood: Better or Worse?" Cambridge Journal of Economics, 23(5): 543-564.

Korenman, Sanders and David Neumark (1992), "Marriage, Motherhood, and Wages." Journal of Human Resources, 27(2): 233255.

Mincer, Jacob and Solomon Polachek (1974), "Family Investments in Human Capital: Earnings of Women", Journal of Political Economy, 82: 576-608.

Neumark, David and Sanders Korenman (1994), "Sources of Bias in Women's Wage Equations: Results Using Sibling Data", Journal of Human Resources, 29: 379-405. 
Rosholm, Michael and Nina Smith (1996), "The Danish Gender Wage Gap in the 1980s: A Panel Data Study", Oxford Economic Papers, 48: 254-279.

Sainsbury, Diane (1994), Gendering Welfare States. Thousand Oaks: Sage Publications.

Waldfogel, Jane (1997a), "Working Mothers Then and Now: A CrossCohort Analysis of the Effects of Maternity Leave on Women's Pay", in Francine Blau and Ronald Ehrenberg (eds.), Gender and Family Issues in the Workplace. New York: Russell Sage.

Waldfogel, Jane (1997b), “The Wage Effects of Children", American Sociological Review, 62 (April): 209-217.

Waldfogel, Jane (1998), “Understanding the 'Family Gap' in Pay for Women with Children", Journal of Economic Perspectives, 12(1): 137156. 


\section{Table 1: Employment Rates of Men and Women Age 24-44 in the Sample Countries}

\begin{tabular}{|c|c|c|c|c|c|c|c|}
\hline $\begin{array}{l}\text { A. Share } \\
\text { Employed }\end{array}$ & $\begin{array}{l}\text { AU } 1995 \\
(N=4,980)\end{array}$ & $\begin{array}{c}\text { CN 1994 } \\
(\mathrm{N}=30,227)\end{array}$ & $\begin{array}{l}\text { UK } 1995 \\
(N=4,403)\end{array}$ & $\begin{array}{c}\text { US } 1994 \\
(\mathrm{~N}=39,540)\end{array}$ & $\begin{array}{l}\text { GE } 1994 \\
(N=5,113)\end{array}$ & $\begin{array}{c}\text { FI } 1991 \\
(N=9,804)\end{array}$ & $\begin{array}{l}\text { SW } 1991 \\
(N=2,184)\end{array}$ \\
\hline All men & .866 & .780 & .812 & .856 & .871 & .704 & .793 \\
\hline All women & .618 & .683 & .640 & .660 & .700 & .738 & .836 \\
\hline $\begin{array}{l}\text { Women } \\
\text { without } \\
\text { children }\end{array}$ & .813 & .780 & .840 & .788 & .822 & .814 & .842 \\
\hline $\begin{array}{l}\text { Women with } \\
\text { children }\end{array}$ & .520 & .639 & .552 & .598 & .639 & .706 & .833 \\
\hline $\begin{array}{l}\text { Gender gap } \\
\text { (line } 2-\text { line } 1)\end{array}$ & -.248 & -.097 & -.170 & -.196 & -.171 & .034 & .043 \\
\hline $\begin{array}{l}\text { Family gap } \\
\text { (line } 4-\text { line } 3 \text { ) }\end{array}$ & -.293 & -.141 & -.288 & -.190 & -.183 & -.108 & -.009 \\
\hline $\begin{array}{l}\text { B. Share } \\
\text { Employed FT }\end{array}$ & AU 1995 & CN 1994 & UK 1995 & "US 1994 & GE 1994 & FI 1991 & $\begin{array}{c}\text { SW } \\
1991\end{array}$ \\
\hline All men & .834 & .752 & .799 & .833 & .842 & .695 & .771 \\
\hline All women & .408 & .518 & .411 & .564 & .509 & .695 & .653 \\
\hline $\begin{array}{l}\text { Women } \\
\text { without } \\
\text { children }\end{array}$ & .721 & .661 & .764 & .730 & .724 & .794 & .745 \\
\hline $\begin{array}{l}\text { Women with } \\
\text { children }\end{array}$ & .253 & .452 & .255 & .483 & .402 & .655 & .611 \\
\hline $\begin{array}{l}\text { Gender gap } \\
\text { (line } 1 \text { - line 2) }\end{array}$ & -.426 & -.234 & -.388 & -.269 & -.333 & .000 & -.118 \\
\hline $\begin{array}{l}\text { Family gap } \\
\text { (line } 3 \text { - line } 4 \text { ) }\end{array}$ & -.468 & -.209 & -.509 & -.247 & -.322 & -.139 & -.134 \\
\hline
\end{tabular}

Notes: Authors' estimates from LIS data. Employment is defined as the share who have a job during the survey week. Full-time employment is defined as the share who have a job during the survey week and who work 30 or more hours per week. 


\section{Table 2: Mean Hourly Wages of Women as a Percentage of Mean Hourly Wages of Men in the Sample Countries}

\begin{tabular}{|c|c|c|c|c|c|c|c|}
\hline $\begin{array}{l}\text { A. Women's } \\
\text { Wage / All } \\
\text { Men's Wage (in } \\
\%)\end{array}$ & $\begin{array}{l}\text { AU } 1994 \\
(N=3,474)\end{array}$ & $\begin{array}{c}\mathrm{CN} 1994 \\
(\mathrm{~N}=20,497)\end{array}$ & $\begin{array}{l}\text { UK } 1995 \\
(N=3,166)\end{array}$ & $\begin{array}{c}\text { US } 1994 \\
(\mathrm{~N}=32,806)\end{array}$ & $\begin{array}{l}\text { GE } 1994 \\
(N=3,607)\end{array}$ & $\begin{array}{c}\text { FI } 1991 \\
(N=7,604)\end{array}$ & $\begin{array}{l}\text { SW 1991 } \\
(N=1,755)\end{array}$ \\
\hline All women & 88.2 & 81.9 & 74.6 & 78.3 & 86.6 & 81.7 & 83.9 \\
\hline $\begin{array}{l}\text { Women } \\
\text { without } \\
\text { children }\end{array}$ & 84.5 & 81.8 & 82.2 & 82.9 & 88.2 & 82.0 & 85.0 \\
\hline $\begin{array}{l}\text { Women with } \\
\text { children }\end{array}$ & 91.4 & 82.0 & 69.6 & 75.6 & 85.5 & 81.6 & 83.4 \\
\hline $\begin{array}{l}\text { Gender gap } \\
\text { (line } 1-100 \%)\end{array}$ & -11.8 & -18.1 & -25.4 & -21.7 & -13.3 & -18.3 & -16.1 \\
\hline $\begin{array}{l}\text { Family gap } \\
\text { (line 3-line 2) }\end{array}$ & 6.9 & 0.2 & -12.6 & -7.3 & -2.7 & -0.4 & -1.6 \\
\hline $\begin{array}{l}\text { B. FT Women's } \\
\text { Wage / FT } \\
\text { Men's Wage } \\
\text { (in \%) }\end{array}$ & $\begin{array}{l}\text { AU 1994 } \\
(\mathrm{N}=2,909)\end{array}$ & $\begin{array}{c}\text { CN 1994 } \\
(\mathrm{N}=17,743)\end{array}$ & $\begin{array}{l}\text { UK } 1995 \\
(\mathrm{~N}=2,573)\end{array}$ & $\begin{array}{c}\text { US } 1994 \\
(\mathrm{~N}=27,400)\end{array}$ & $\begin{array}{c}\text { GE 1994 } \\
(N=3,135)\end{array}$ & $\begin{array}{c}\text { FI } 1991 \\
(\mathrm{~N}=6,813)\end{array}$ & $\begin{array}{l}\text { SW 1991 } \\
(N=1,541)\end{array}$ \\
\hline All FT & 84.2 & 75.6 & 81.1 & 79.0 & 83.8 & 78.8 & 82.7 \\
\hline $\begin{array}{l}\text { FT without } \\
\text { children }\end{array}$ & 84.8 & 78.8 & 83.2 & 83.4 & 88.3 & 80.4 & 85.6 \\
\hline $\begin{array}{l}\text { FT with } \\
\text { children }\end{array}$ & 83.4 & 73.4 & 78.5 & 74.7 & 79.3 & 78.0 & 81.0 \\
\hline $\begin{array}{l}\text { Gender gap } \\
\text { (line } 1-100 \%)\end{array}$ & -15.8 & -24.4 & -18.9 & -21.0 & -16.2 & -21.2 & -17.3 \\
\hline $\begin{array}{l}\text { Family gap } \\
\text { (line 3-line 2) }\end{array}$ & -1.4 & -5.4 & -4.7 & -8.7 & -9.0 & -2.4 & -4.6 \\
\hline
\end{tabular}

Note: Wages are defined as gross annual earnings divided by annual hours worked (the product of weeks worked and hours per week). 


\section{Table 3: Effects of Marriage and Age of Youngest Child on Women's Employment, Coefficients (and Standard Errors) from OLS Models}

\begin{tabular}{|c|c|c|c|c|c|c|c|}
\hline \multicolumn{8}{|c|}{ A. Employment } \\
\hline & AU 94 & CN94 & UK 95 & US 94 & GE 94 & FI 91 & SW 91 \\
\hline \multirow[t]{2}{*}{ Married } & .035 & $.056^{* *}$ & $.049^{* *}$ & -.003 & -.018 & .008 & $-.065^{*}$ \\
\hline & $(.023)$ & $(.009)$ & $(.022)$ & $(.007)$ & $(.023)$ & $(.017)$ & $(.036)$ \\
\hline \multirow{2}{*}{$\begin{array}{l}\text { Child Age } \\
<1\end{array}$} & $-.576^{* *}$ & $-.233^{* *}$ & $-.363^{* *}$ & $-.242^{* *}$ & $-.442^{* *}$ & $-.104^{* *}$ & $-.115^{*}$ \\
\hline & $(.035)$ & $(.015)$ & $(.034)$ & $(.013)$ & $(.163)$ & $(.030)$ & $(.069)$ \\
\hline \multirow{2}{*}{$\begin{array}{l}\text { Child age } \\
1-5\end{array}$} & $-.349 * *$ & $-.183^{* *}$ & $-.313^{* *}$ & $-.185^{* *}$ & $-.305^{* *}$ & $-.102 * *$ & $-.089 * *$ \\
\hline & $(.024)$ & $(.010)$ & $(.023)$ & $(.008)$ & $(. .027)$ & $(.018)$ & $(.033)$ \\
\hline \multirow[t]{2}{*}{ Child 6-17 } & $-.152^{* *}$ & $-.076^{*}$ & $-.085^{* *}$ & $-.060^{* *}$ & $-.096^{* *}$ & .023 & -.002 \\
\hline & $(.023)$ & $(.009)$ & $(.024)$ & $(.008)$ & $(.024)$ & $(.017)$ & $(.034)$ \\
\hline $\mathrm{N}$ & 2,669 & 16,077 & 2,438 & 22,091 & 2,372 & 4,870 & 1,060 \\
\hline Adj R2 & .2133 & .1498 & .2768 & .1160 & .1351 & .1545 & .0597 \\
\hline \multicolumn{8}{|c|}{ B. Full-time Employment } \\
\hline & AU 94 & CN 94 & UK 95 & US 94 & GE 94 & FI 91 & SW 91 \\
\hline \multirow[t]{2}{*}{ Married } & .003 & $.020^{* *}$ & .007 & $-.022^{* *}$ & $-.084^{* *}$ & -.017 & $-.090^{*}$ \\
\hline & $(.023)$ & $(.009)$ & $(.022)$ & $(.008)$ & $(.024)$ & $(.018)$ & $(.046)$ \\
\hline \multirow{2}{*}{$\begin{array}{l}\text { Child age } \\
<1\end{array}$} & $-.595^{* *}$ & $-.250^{* *}$ & $-.474^{* *}$ & $-.280^{* *}$ & $-.483^{* *}$ & $-.098^{* *}$ & -.028 \\
\hline & $(.034)$ & $(.016)$ & $(.034)$ & $(.014)$ & $(.169)$ & $(.031)$ & $(.090)$ \\
\hline \multirow{2}{*}{$\begin{array}{l}\text { Child age } \\
1-5\end{array}$} & $-.496^{* *}$ & $-.246^{* *}$ & $-.519 * *$ & $-.264^{* * *}$ & $-.450^{* *}$ & $-.134^{* *}$ & $-.146^{* *}$ \\
\hline & $(.023)$ & $(.010)$ & $(.023)$ & $(.009)$ & $(.028)$ & $(.019)$ & $(0.42)$ \\
\hline \multirow[t]{2}{*}{ Child 6-17 } & $-.326^{* *}$ & $-.129 * *$ & $-.356^{* *}$ & $-.120^{* *}$ & $-.242^{* *}$ & .012 & $-.096^{* *}$ \\
\hline & $(.023)$ & $(.010)$ & $(.024)$ & $(.009)$ & $(.025)$ & $(.017)$ & $(.043)$ \\
\hline $\mathrm{N}$ & 2,654 & 16,077 & 2,438 & 21,682 & 2,372 & 4,870 & 1,060 \\
\hline Adj R2 & .2678 & .11158 & .3141 & .1154 & .2220 & .1574 & .0547 \\
\hline
\end{tabular}

Notes: Employment and full-time employment models also include controls for age, age squared, education, race or ethnicity (except in Sweden), presence of a working husband/partner, other family members' earnings, other family income, region, and urban residence (except in Germany). See appendix for variable definitions. Complete regression results are available from the authors on request.

* indicates statistically significant at $\mathrm{p}<.10$

** indicates statistically significant at $\mathrm{p}<.05$ 
Table 4: Effects of Marriage and Children on Log of Women's Hourly Wages, Coefficients (and Standard Errors) from OLS Regressions

\begin{tabular}{|c|c|c|c|c|c|c|c|}
\hline \multicolumn{8}{|c|}{ 1. All workers } \\
\hline & AU 94 & CN 94 & UK 95 & US 94 & GE 94 & FI 91 & SW 91 \\
\hline \multirow[t]{2}{*}{ Married } & .035 & -.008 & .043 & $.072^{* *}$ & -.037 & $.037^{* *}$ & $.033^{*}$ \\
\hline & $(.038)$ & $(.016)$ & $(.027)$ & $(.009)$ & $(.031)$ & $(.017)$ & $(.018)$ \\
\hline \multirow[t]{2}{*}{ One child } & -.074 & $-.037^{* *}$ & $-.082^{* *}$ & $-.039 * *$ & -.017 & $-0.42^{* *}$ & -.008 \\
\hline & $(.045)$ & $(.018)$ & $(.030)$ & $(.011)$ & $(.034)$ & $(.018)$ & $(0.21)$ \\
\hline \multirow{2}{*}{$\begin{array}{l}\text { Two } \\
\text { children }\end{array}$} & $-.107^{* *}$ & $-.053^{* *}$ & $-.243^{* *}$ & $-.074^{* *}$ & $-.112^{* *}$ & -.025 & -.014 \\
\hline & $(.044)$ & $(.018)$ & $(.030)$ & $(.012)$ & $(.039)$ & $(.018)$ & $(.021)$ \\
\hline \multirow{2}{*}{$\begin{array}{l}\text { Three or } \\
\text { more } \\
\text { children }\end{array}$} & $-.101^{*}$ & $-.126^{* *}$ & $-.306^{* *}$ & $-.114^{* *}$ & .022 & $-.058^{* *}$ & -.025 \\
\hline & $(.058)$ & $(.024)$ & $(.042)$ & $(.014)$ & $(.061)$ & $(.023)$ & $(.025)$ \\
\hline $\mathrm{N}$ & 1,547 & 10,219 & 1,564 & 15,307 & 1,515 & 3,592 & 874 \\
\hline Adj R2 & .0635 & .0936 & .2967 & .2297 & .1352 & .2473 & .1787 \\
\hline \multicolumn{8}{|c|}{ 2. Full-time workers only } \\
\hline & AU 94 & CN 94 & UK 95 & US 94 & GE 94 & FI 91 & SW 91 \\
\hline \multirow[t]{2}{*}{ Married } & .028 & -.004 & .018 & $.075^{* *}$ & .002 & .024 & $.037^{* *}$ \\
\hline & $(.036)$ & $(.016)$ & $(.030)$ & $(.010)$ & $(.030)$ & $(.015)$ & $(.018)$ \\
\hline \multirow[t]{2}{*}{ One child } & $-.122^{* *}$ & $-.058^{* *}$ & .003 & $-.025^{* *}$ & -.032 & $-.054^{* *}$ & -.031 \\
\hline & $(.046)$ & $(.017)$ & $(.036)$ & $(.012)$ & $(.035)$ & $(.016)$ & $(.021)$ \\
\hline \multirow{2}{*}{$\begin{array}{l}\text { Two } \\
\text { children }\end{array}$} & $-.167^{* *}$ & $-.065^{* *}$ & $-.176^{* *}$ & $-.048^{* *}$ & $-.080^{*}$ & $-.034^{* *}$ & $-.056^{* *}$ \\
\hline & $(.048)$ & $(.018)$ & $(.037)$ & $(.012)$ & $(.041)$ & $(.017)$ & $(.021)$ \\
\hline \multirow{2}{*}{$\begin{array}{l}\text { Three or } \\
\text { more } \\
\text { children }\end{array}$} & $-.244^{* *}$ & $-.203^{* *}$ & $-.295^{* *}$ & $-.102^{* *}$ & $-.134^{* *}$ & $-.082^{* *}$ & $-.102^{* *}$ \\
\hline & $(.073)$ & $(.025)$ & $(.054)$ & $(.016)$ & $(.078)$ & $(.022)$ & $(.027)$ \\
\hline $\mathrm{N}$ & 1,046 & 7,885 & 1,002 & 11,588 & 1,107 & 3,385 & 685 \\
\hline Adj R2 & .0934 & .1444 & .3125 & .2678 & .1674 & .3037 & .1996 \\
\hline
\end{tabular}

Notes: Log wage models include controls for age, age squared, education, race or ethnicity (except for Sweden), region, and urban residence (except for Germany). Model 1 is estimated for all workers; model 2 is estimated only for full-time workers (those who work 30 or more hours per week). See appendix for variable definitions. Complete regression results available from the authors on request. 
Table 5: Effects of Marriage and Children on Log of Women's Hourly Wages, Coefficients (and Standard Errors) from OLS Regressions, Corrected for Sample Selection Bias

\begin{tabular}{lccccccc}
\hline \hline & AU 94 & CN 94 & UK 95 & US 94 & GE 94 & FI 91 & SW 91 \\
\hline Married & .037 & -.009 & $.048^{*}$ & $.059^{* *}$ & -.031 & $.034^{* *}$ & $.033^{* *}$ \\
& $(.038)$ & $(.017)$ & $(.027)$ & $(.010)$ & $(.031)$ & $(.017)$ & $(.018)$ \\
One child & $-.086^{*}$ & $-.035^{* *}$ & $-.093^{* *}$ & $-.067^{* *}$ & -.019 & $-.044^{* *}$ & -.006 \\
& $(.049)$ & $(.019)$ & $(.033)$ & $(.013)$ & $(0.37)$ & $(.018)$ & $(.021)$ \\
Two children & $-.120^{* *}$ & $-.050^{* *}$ & $-.255^{* *}$ & $-.105^{* *}$ & $-.107^{* *}$ & -.027 & -.013 \\
& $(.048)$ & $(.019)$ & $(.032)$ & $(.013)$ & $(.042)$ & $(.019)$ & $(.020)$ \\
Three or more & $-.113^{* *}$ & $-.123^{* *}$ & $-.321^{* *}$ & $-.152^{* *}$ & .003 & $-.063^{* *}$ & -.026 \\
children & $(.061)$ & $(.026)$ & $(.044)$ & $(.016)$ & $(.064)$ & $(.024)$ & $(.025)$ \\
Lambda & .030 & -.011 & .031 & $.162^{* *}$ & .019 & .028 & -.028 \\
& $(.049)$ & $(.033)$ & $(.034)$ & $(.031)$ & $(.055)$ & $(.024)$ & $(.043)$ \\
$\mathrm{N}$ & 1,046 & 16,077 & 2,438 & 22,091 & 1,107 & 4,870 & 685 \\
\hline \hline
\end{tabular}

Notes: Log wage models include controls for age, age squared, education, race or ethnicity (except for Sweden), region, and urban residence. Model is estimated for all women in the sample using the standard sample selection correction technique as described in the text. See appendix for variable definitions. Complete regression results available from the authors on request. 


\section{Table 6: Mean Percentile Ranking of Women in the Male Wage Distribution}

\begin{tabular}{|c|c|c|c|c|c|c|c|}
\hline & AU 94 & $\mathrm{CN} 94$ & UK 95 & US 94 & GE 94 & FI 91 & SW91 \\
\hline 1. All women & 40.19 & 37.15 & 33.54 & 38.78 & 39.48 & 35.75 & 30.95 \\
\hline \multicolumn{8}{|l|}{ 2. All workers: } \\
\hline $\begin{array}{l}\text { a. Women without } \\
\text { children }\end{array}$ & 40.00 & 38.47 & 40.37 & 42.36 & 43.04 & 36.32 & 31.68 \\
\hline $\begin{array}{l}\text { b. Women with } \\
\text { children }\end{array}$ & 40.34 & 36.42 & 28.95 & 36.64 & 37.05 & 35.48 & 30.62 \\
\hline $\begin{array}{l}\text { c. Family gap for all } \\
\text { workers }\end{array}$ & 0.34 & -2.05 & -11.42 & -5.72 & -5.99 & -0.84 & -1.06 \\
\hline \multicolumn{8}{|c|}{ 3. Full-time workers only } \\
\hline $\begin{array}{l}\text { a. Women without } \\
\text { children }\end{array}$ & 39.65 & 37.36 & 41.30 & 43.70 & 42.97 & 36.12 & 32.87 \\
\hline $\begin{array}{l}\text { b. Women with } \\
\text { children }\end{array}$ & 37.87 & 34.07 & 36.04 & 38.28 & 35.42 & 34.48 & 28.53 \\
\hline $\begin{array}{l}\text { c. Family gap for full- } \\
\text { time workers }\end{array}$ & -1.78 & -3.29 & -5.26 & -5.42 & -7.55 & -1.64 & -4.34 \\
\hline
\end{tabular}

Note: Percentile ranking in the male wage distribution is calculated for each woman, and then the mean for all women in the group is calculated. The family gap for all workers is the mean percentile ranking of women workers with children minus the mean percentile ranking of women workers without children; the family gap for FT workers is the mean percentile ranking of full-time women workers with children minus the mean percentile ranking of full-time women workers without children. 
Figure 1: Female-male hourly earnings ratios, 1967-1995
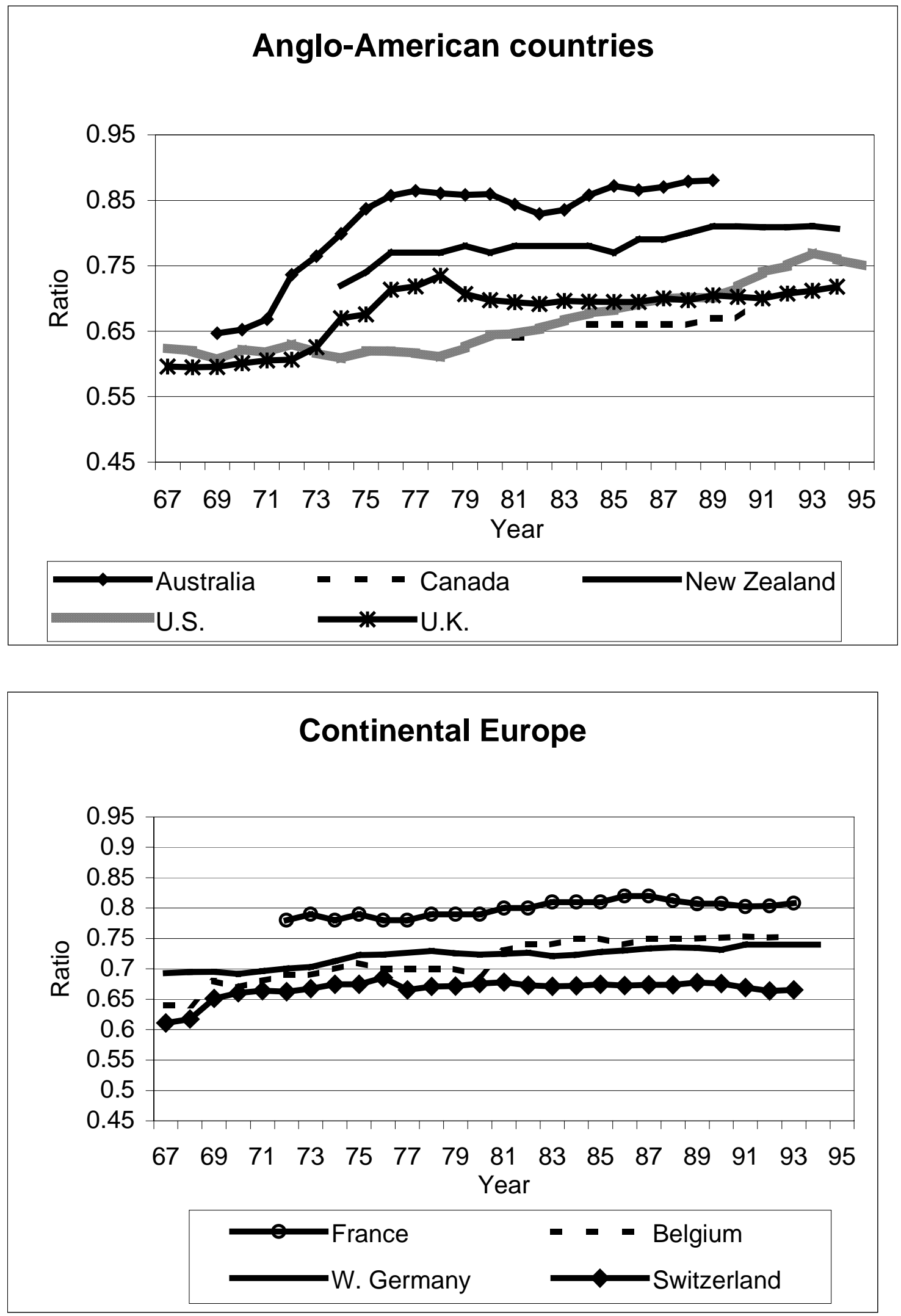
Figure 1 continued

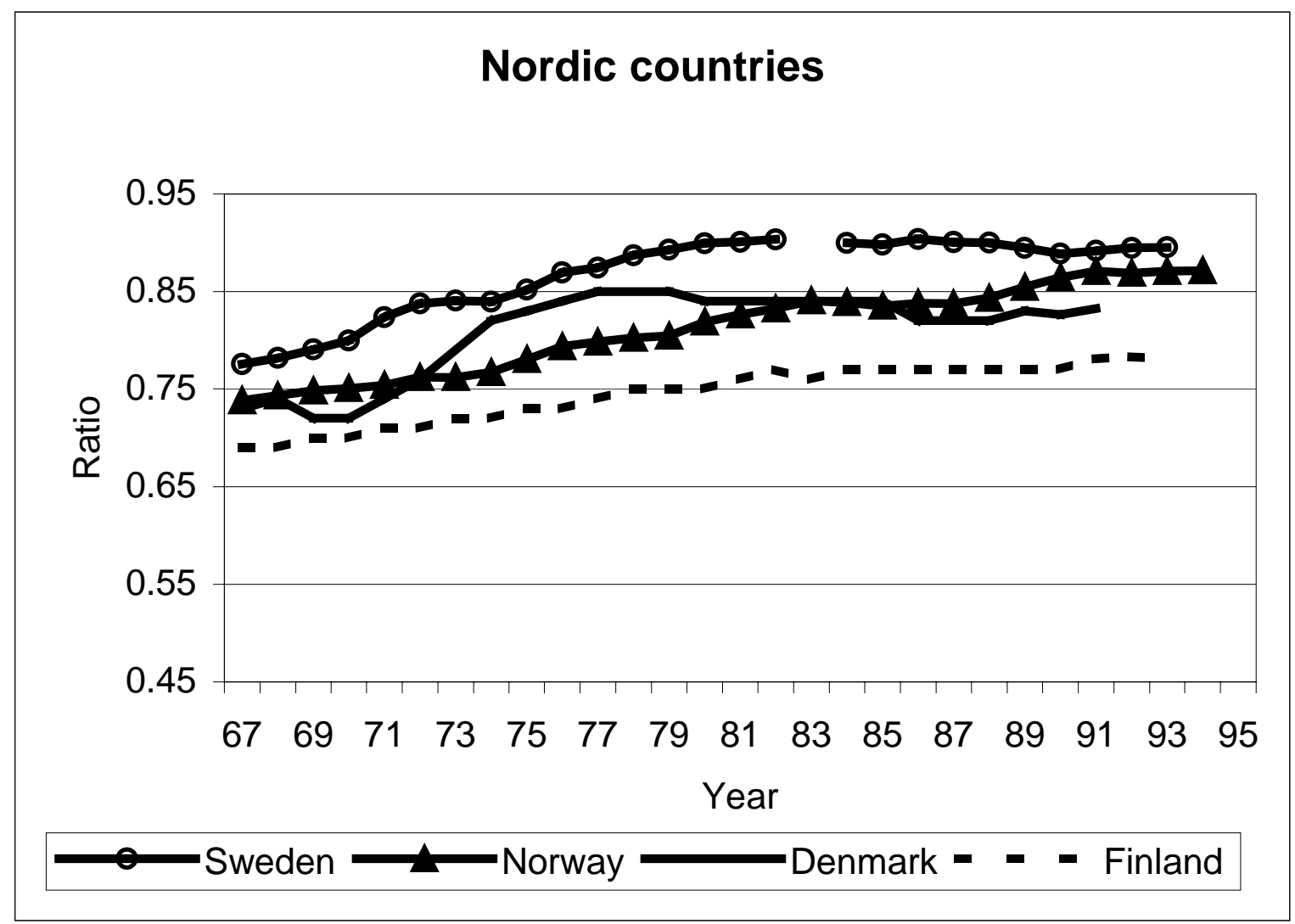


Figure 2: Share employed, by age of the youngest child
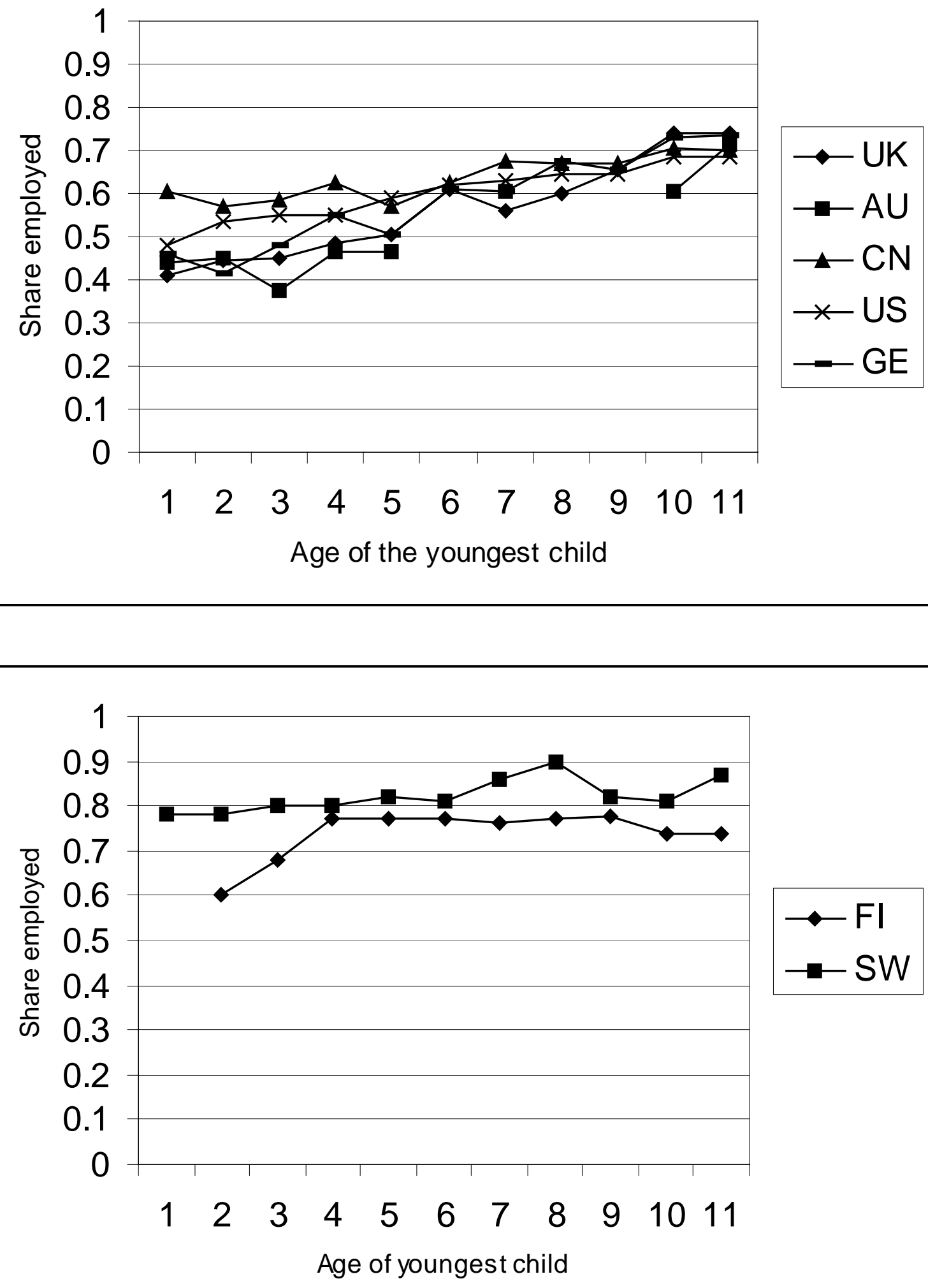
Figure 3: Family Gap in Pay and Gender Gap in Pay

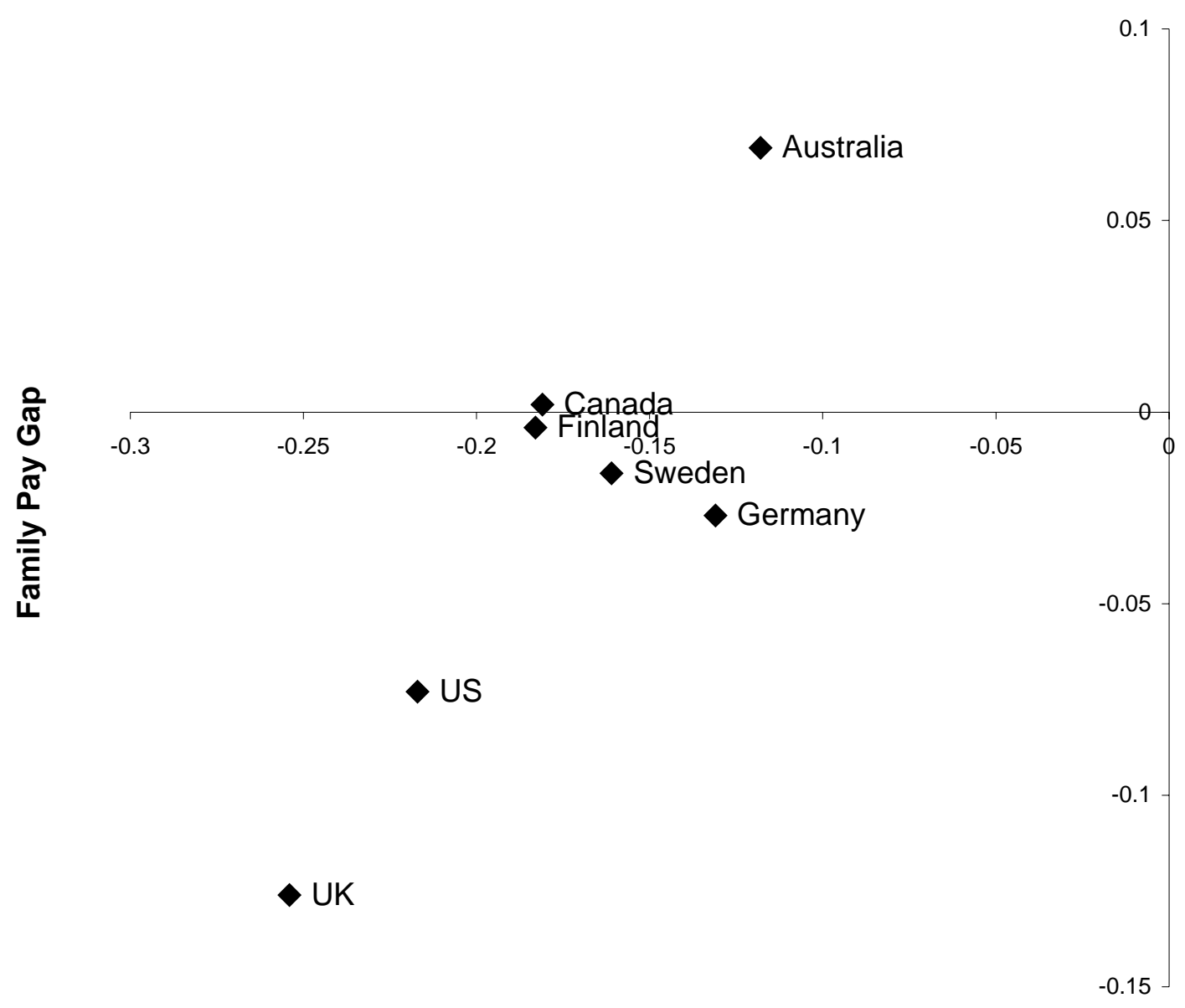

Gender Pay Gap 


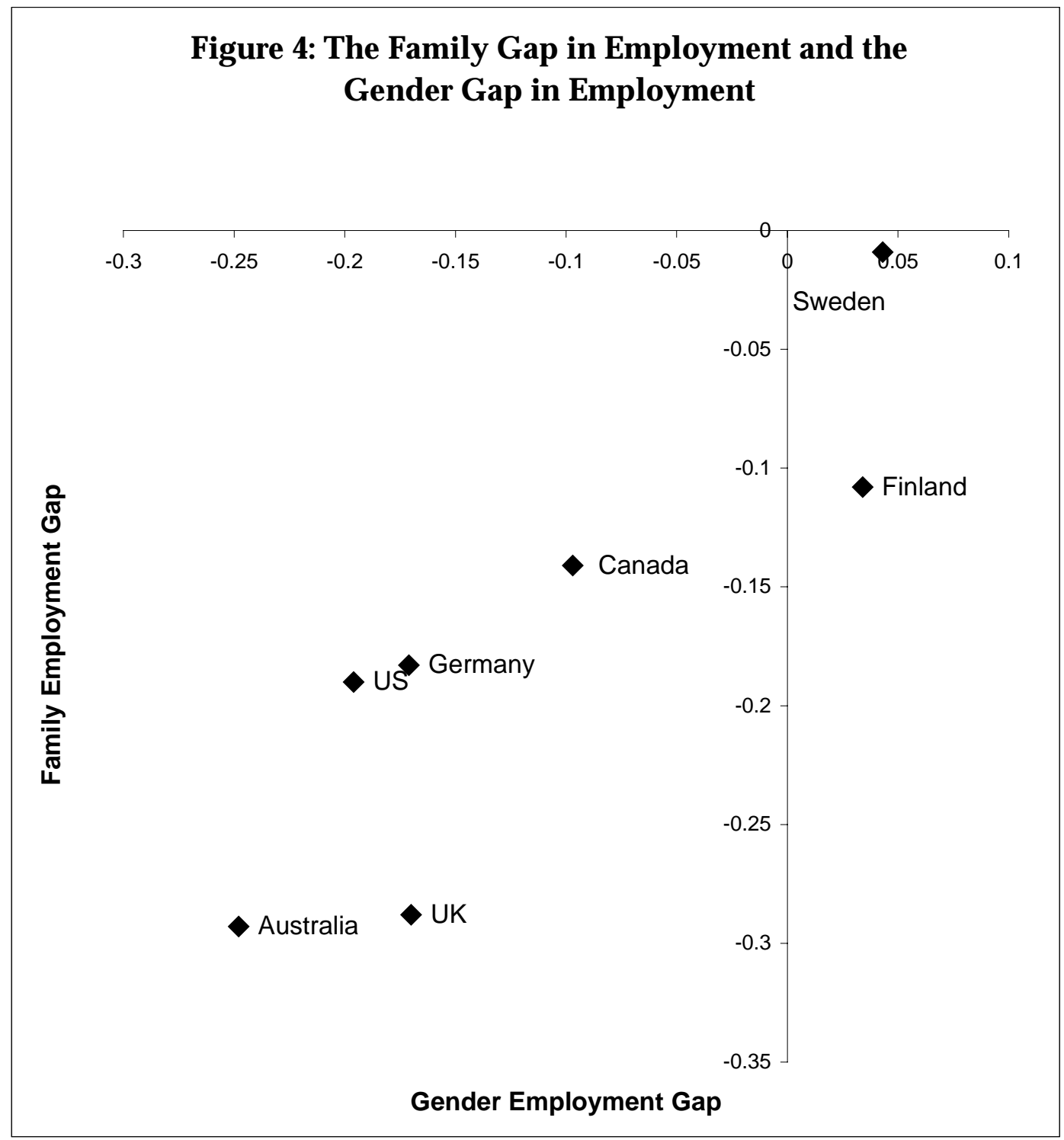




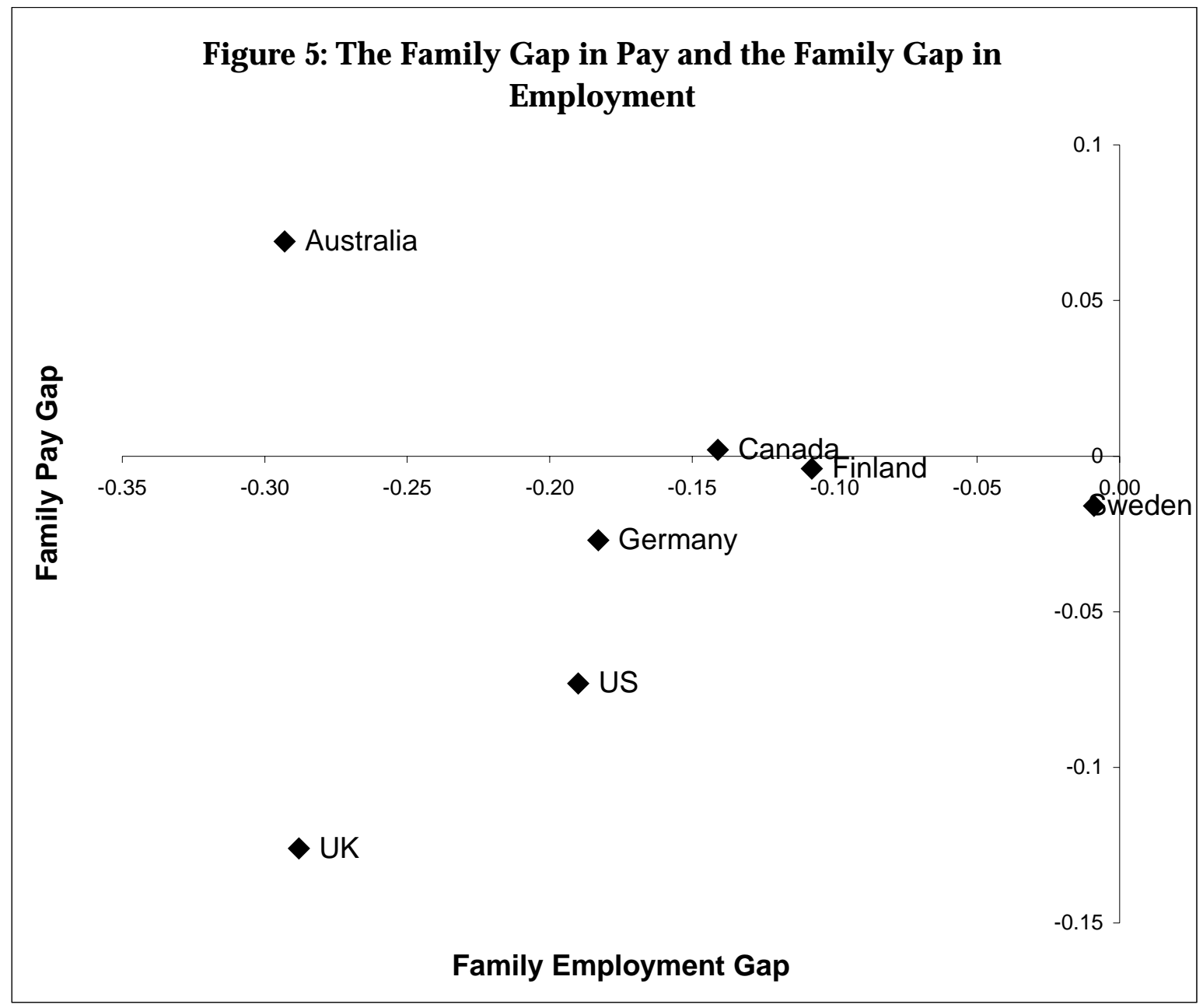


Figure 6: Family gaps in the seven sample countries

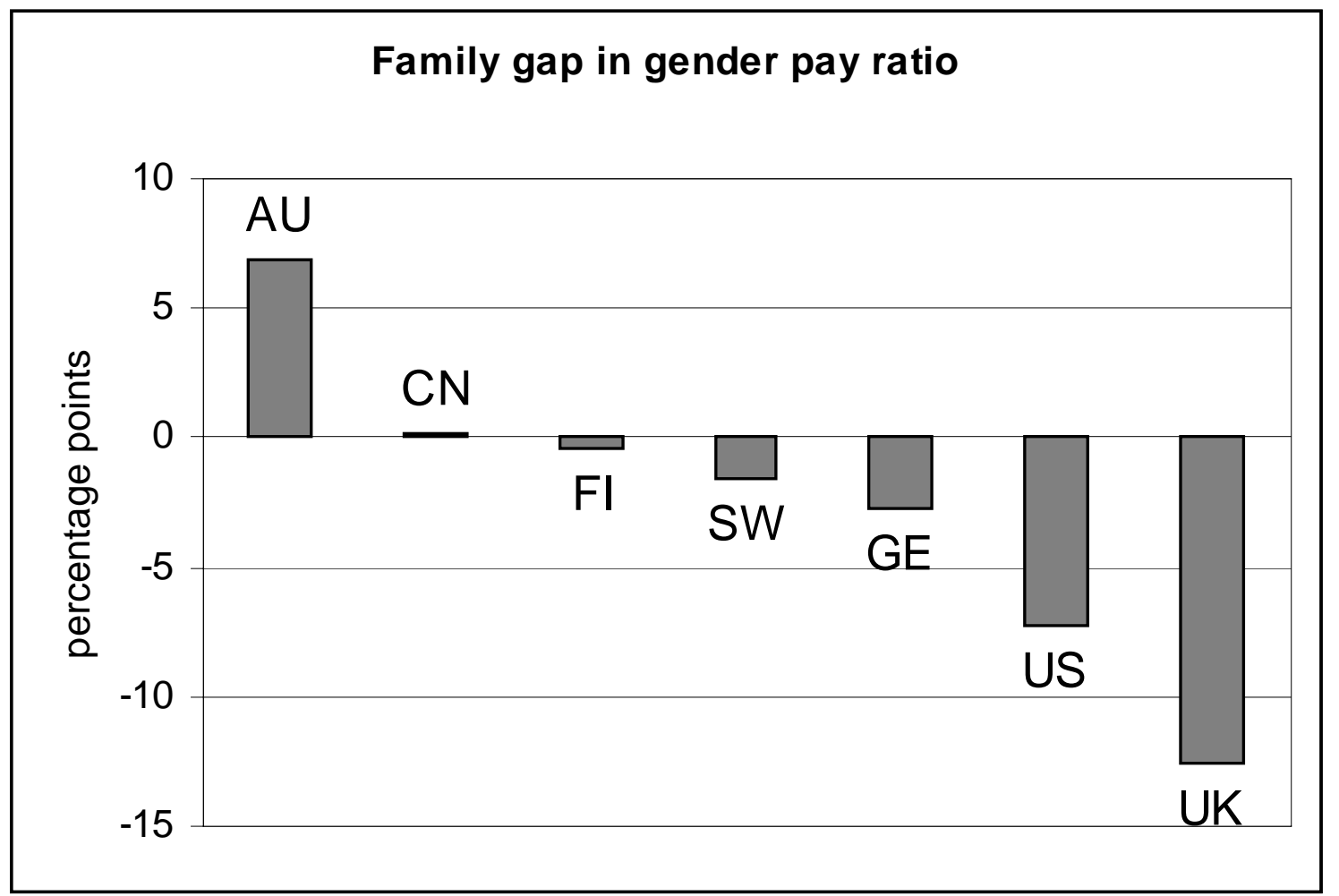

Family gap in mean percentile position

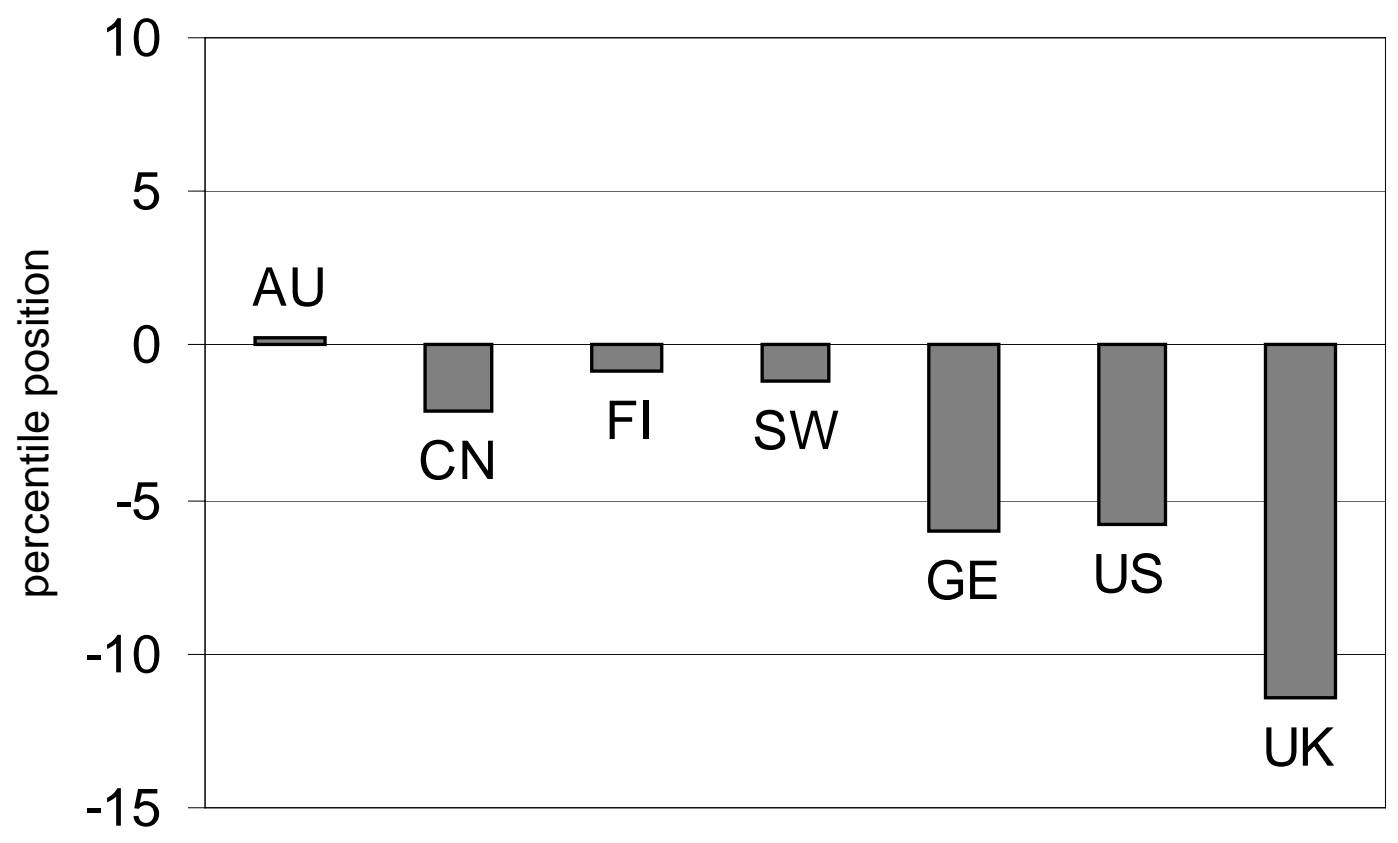


Figure 7: Rankings of the seven sample countries
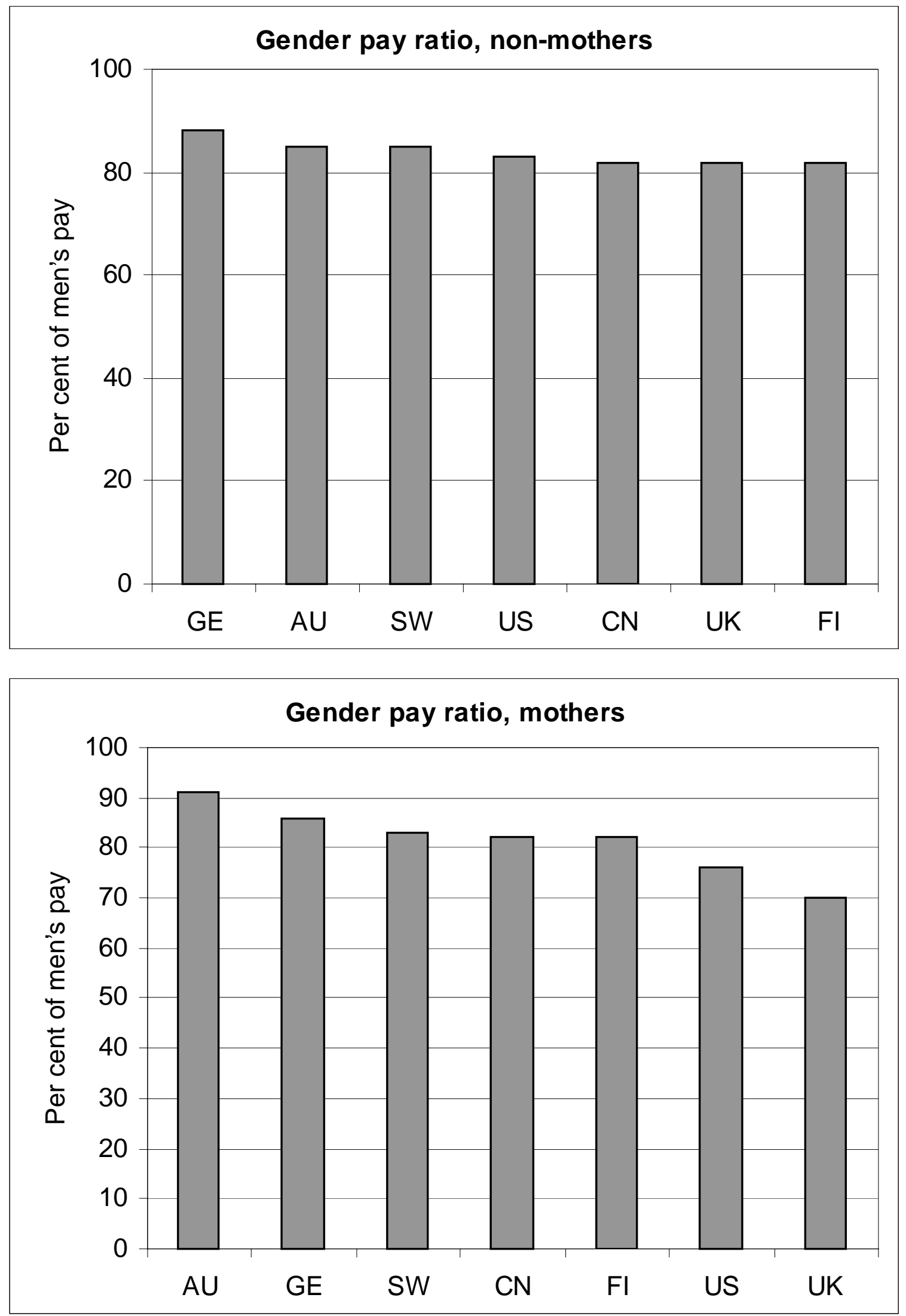
Figure 7 continued
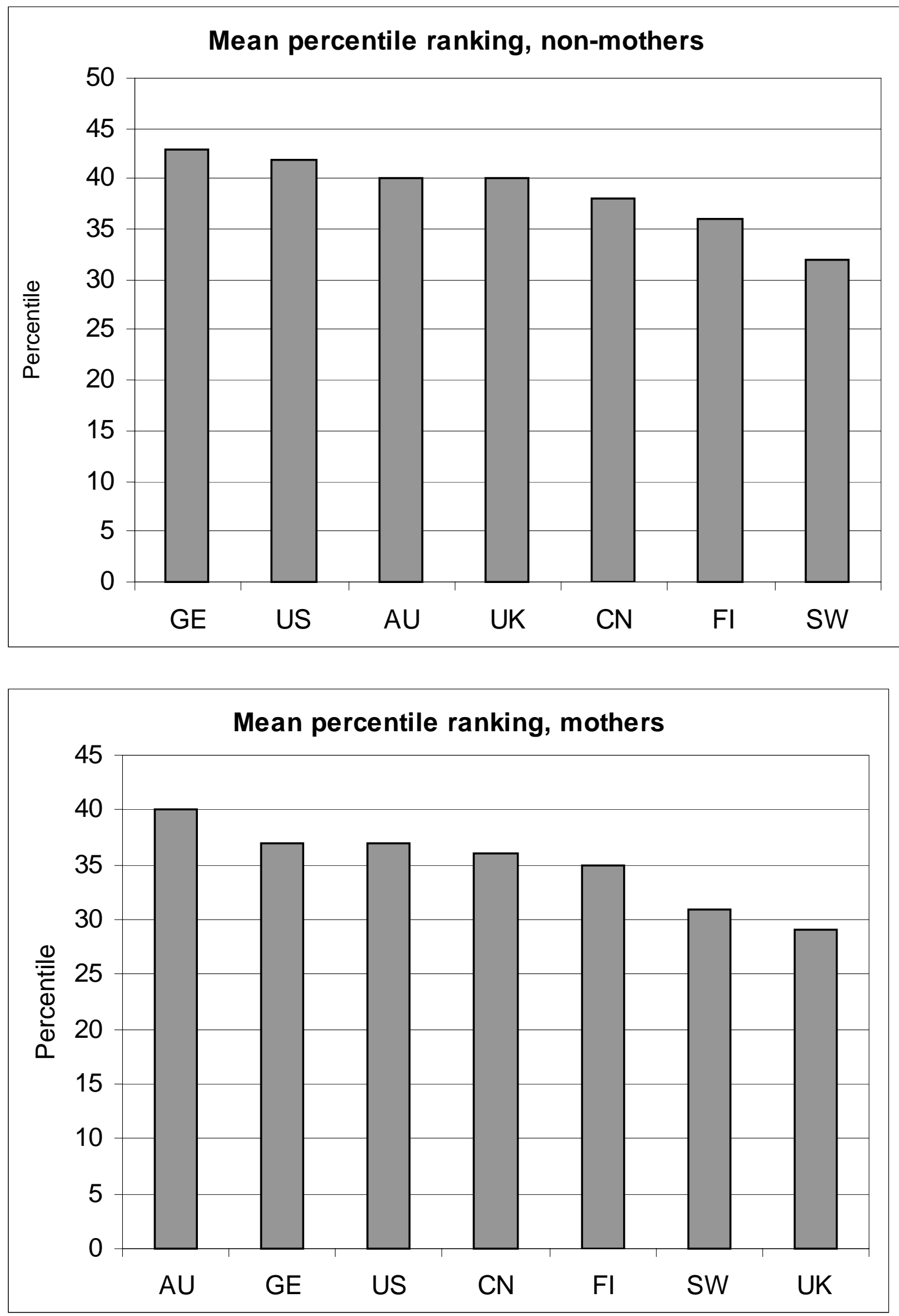


\section{Appendix 1: Variable Definitions}

Employed Dummy variable for whether employed during survey week.

Log wage $\quad$ Log of gross hourly wage (annual wage and salary income divided by weeks worked and hours worked).

Age Age in years.

Age squared Age in years squared.

Married

Child $<1$

Child 1-5 Dummy variable for whether married. Includes those cohabiting or living together as married except in U.S. and GE.

Dummy variable for whether youngest child is under age 1.

Dummy variable for whether youngest child is age 1 to 5.

Child 6-17 Dummy variable for whether youngest child is age 6 to 17.

1 Child Dummy variable for having 1 child.

2 Children Dummy variable for having 2 children.

$3+$ Children Dummy variable for having 3 or more children.

Partner work Dummy variable for whether husband/partner works.

Other earn Other family members' earnings.

Other income Other family income (total family income minus own earnings and other earnings).

Education Dummy variables defined by country:

AU: 8 categories (no qualifications, basic vocational, skilled vocational, associated diploma, undergraduate diploma, bachelor degree, postgraduate diploma, higher degree)

CN: 7 categories (grade 8 or lower, grade 9-10, grade 11-13 not h.s. grad, grade 11-13 h.s. grad, post-secondary no degree, post sec. certificate or diploma, university degree)

UK: 13 categories (left school age 0 to13, 14, 15, 16, 17, $18,19,20,21,22,23,24$ or more)

US: 8 categories (elementary, some high school, high school, some college, associate degree, bachelor degree, masters, doctorate)

GE: 7 categories (no degree, other degree, secondary, tech school degree, high school degree, technical college, university) 
FI 7 categories (no years of schooling, 10-11, 12, 13-

$14,15,16$, post-grad education)

SW 8 categories (unspecified, primary 1, primary 2, secondary 1 , secondary 2 , university 1 , university 2 , research)

Race or Ethnicity /

National Origin

Dummy variables defined by country:

AU: 4 categories (Oceania, Antarctica, Europe or USSR; Africa or Mideast; Asia; Americas)

$\mathrm{CN}$ : 3 categories (English, French, other)

UK: Not available

US: 6 categories (White, Black, Asian/Pacific

Islander, Eskimo/Aleut/Indian, Other Race, Hispanic)

GE: 7 categories (W. German-German, W. German-

Other, Foreign-German, Foreign-Other, E. German-

German, E. German-other, immigrant)

FI: 2 categories (Finnish-speaking, Swedishspeaking)

SW: Not available.

Region Dummy variable defined by country:

AU: 7 categories (New South Wales, Victoria, Queensland, Southern Australia, Western Australia, Tasmania, A.C.T and N.T.)

CN: 10 categories (Newfoundland, Prince Edward Island, Nova Scotia, New Brunswick, Quebec, Ontario, Manitoba, Saskatchewan, Alberta, British Columbia) UK: 11 categories (North, Yorkshire and Humberside North West, East Midlands, West Midlands, East Anglia, Greater London, South East, South West, Wales, Scotland, Northern Ireland)

US: 9 categories (New England, Middle Atlantic, East North Central, North Central, South Atlantic, East South Central, West South Central, Mountain, Pacific) GE: 16 categories (West Berlin, Schleswig Holstein, Hamburg, Lower Saxony, Bremen, North Rhine Westfalia, Hesse, Rhineland, Badenwurttemburg, Bavaria, East Berlin, Mecklenburg, Brandenburg, Sachsen, Thueringen, Saxony) 
FI: 11 categories (Uusimaa, Turku/Pori, Home, Kymi, North Karelia, Kuopio, Central Finland, Vaasa, Oulu, Lapland, other) SW: 7 categories (Stockholm, bigger cities, south, north, north sparsely populated, Gothenburg, Malmo)

Urban Dummy variables defined by country:

AU: 2 categories (state capital, rest of country)

$\mathrm{CN}$ : 6 categories (urban 500,000+, urban 100,000 to 499,999, urban 30,000-99,999, urban 2,500-29,999, urban $<2,500$, rural)

UK: 5 categories (Greater London, Metropolitan districts and central Clyde, non metropolitan, 3.2+ persons, non-metropolitan 0.9-3.2 persons, non metropolitan under 0.9 persons)

US: 9 categories (city $<1,000,000$, city 1-2.5 million, city 2.5-5 million, city $>5$ million, suburb $<1,000,000$, suburb 1-2.5 million, suburb 2.5-5 million, suburb $>5$ million, non-metropolitan)

GE: Not available.

FI: 2 categories (urban, non-urban)

SW: 6 categories 


\section{Appendix 2: Means of Family Status Variables Used in Employment and Wage Models}

\begin{tabular}{lccccccc}
\hline \hline \multicolumn{1}{l}{ A. Employment models } & & & & & & \\
& AU 94 & CN 94 & UK 95 & US 94 & GE 94 & FI 91 & SW 91 \\
\hline Married & .731 & .732 & .737 & .625 & .698 & .773 & .763 \\
Child <1 & .077 & .068 & .080 & .064 & .003 & .052 & .030 \\
Child 1-5 & .269 & .259 & .299 & .294 & .210 & .272 & .323 \\
Child 6-17 & .321 & .342 & .315 & .322 & .454 & .387 & .305 \\
& & & & & & & \\
\hline \hline B. Wage models & & & & & & & \\
& AU 94 & CN 94 & UK 95 & US 94 & GE 94 & FI 91 & SW 91 \\
\hline $\begin{array}{l}\text { Married } \\
\text { One child }\end{array}$ & .708 & .740 & .764 & .6021 & .673 & .748 & .763 \\
Two children & .251 & .226 & .219 & .241 & .292 & .274 & .207 \\
$\begin{array}{l}\text { Three or more } \\
\text { children }\end{array}$ & .109 & .108 & .098 & .132 & .056 & .119 & .154 \\
\hline \hline
\end{tabular}

Note: Means of other variables used in the models, and complete regression results, are available from the authors on request. 